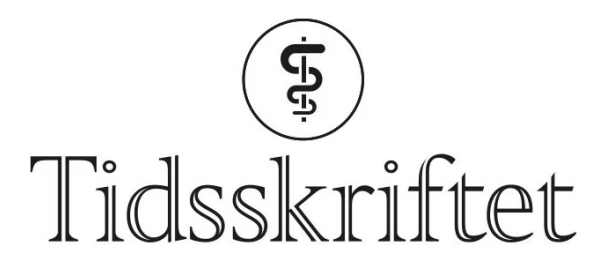

DEN NORSKE LEGEFORENING

\title{
Covid-19-vaksiner gir økt risiko for anafylaksi
}

DEBATT

\section{MARIE ALNAES}

mariealnaes1@gmail.com

Marie Alnæs er spesialist i øre-nese-hals-sykdommer og overlege ved Seksjon for klinisk spesialallergologi, Yrkesmedisinsk avdeling, Haukeland universitetssjukehus.

Forfatteren har fylt ut ICMJE-skjemaet og oppgir ingen interessekonflikter.

\section{TORGEIR STORAAS}

Torgeir Storaas er ph.d., spesialist i øre-nese-hals-sykdommer, seksjonsoverlege ved Seksjon for klinisk spesialallergologi, Yrkesmedisinsk avdeling, Haukeland universitetssjukehus og leder for Regionalt senter for astma, allergi og anna overfølsemd i Helse Vest.

Forfatteren har fylt ut ICMJE-skjemaet og oppgir ingen interessekonflikter.

\section{MARTIN SØRENSEN}

Martin Sørensen er ph.d., spesialist i barnesykdommer og i allmennmedisin og Leder for Regionalt senter for astma, allergi og overfølsomhet i Helse Nord, Universitetssykehuset i Nord-Norge. Forfatteren har fylt ut ICMJE-skjemaet og oppgir ingen interessekonflikter.

\section{EVA STYLIANOU}

Eva Stylianou er dr.med., spesialist i lungesykdommer og i indremedisin og seksjonsleder for Regionalt senter for astma, allergi og overfølsomhet i Helse $\varnothing \emptyset r-\emptyset$ st, Oslo universitetssykehus. Forfatteren har fylt ut ICMJE-skjemaet og oppgir ingen interessekonflikter.

\section{ANDERS TØNDELL}

Anders Tøndell er spesialist i lungesykdommer og leder for Regionalt senter for astma, allergi og overfølsomhet i Helse Midt-Norge, St. Olavs hospital.

Forfatteren har fylt ut ICMJE-skjemaet og oppgir ingen interessekonflikter.

\section{I den planlagte massevaksinasjonen vil man oppleve at mange pasienter får allergiske reaksjoner og anafylaksi. Det er viktig at disse pasientene utredes.}

De nye vaksinene mot covid-19 har en økt anafylaksitendens sammenlignet med andre vaksiner $(\underline{\mathbf{1}}, \underline{2})$. Det er anslått at forekomsten er på 2,5-11,1 per million doser, mens den er o,8 per million for andre vaksiner $(\underline{1}, \underline{2})$. Under den planlagte massevaksinasjonen vil man få 
flere pasienter med anafylaksi, i tillegg til andre allergiske reaksjoner på vaksinen. Disse må følges opp korrekt.

Det er mistanke om at fyllstoffene polyetylenglykol (PEG) 2000 (Moderna og BioNTech) og polysorbat 80 (AstraZeneca) kan være årsaken til den økte forekomsten av anafylaksi $(3,4$.). Polyetylenglykol er bredt brukt både i injiserbare, perorale og topikale medikamenter, men er ikke tidligere brukt i vaksiner. Dette stoffet er, som polysorbat, et kjent allergen som anses som underdiagnostisert (5). European Academy of Allergy and Clinical Immunology har laget en intensjonsrapport (position paper) for allergi og covid-19-vaksiner, der det klart anbefales utredning av pasienter som har reagert på vaksinen (므). En nasjonal fagprosedyre for utredning av allergiske reaksjoner etter koronavaksiner blir nå utarbeidet av det norske allergologiske fagmiljøet.

\section{For mange tolkes som allergiske}

Mange vaksinereaksjoner er ikke allergiske, men kan ligne klinisk. Typiske allergiske reaksjoner er urtikaria/erytem med kløe, angioødem, astmaanfall og anafylaksi.

Erfaring fra annen massevaksinasjon, som influensavaksinering, er at for mange reaksjoner tolkes som allergiske. Å utrede vaksinereaksjoner og få avkreftet allergi mot innholdsstoffene vil muliggjøre at flere får vaksine, slik at vi raskere kan bekjempe pandemien. Det er viktig for pasienten å få avklart reell allergi mot vaksinens innholdsstoffer, da dette får følger for senere valg av medikamentell behandling.

\section{Kort tidsvindu}

For pasienter som har reagert på første dose, er det et kort tidsvindu for utredning av Moderna- og BioNTech-vaksinen, da allergologisk utredning kan finne sted først fire uker etter reaksjonen, men må gjennomføres innen seks uker for å muliggjøre dose nummer to. For AstraZenecas vaksine har man opp til tolv uker etter første dose. Pasientene bør derfor henvises så snart som mulig. Ta gjerne kontakt med nærmeste regionale senter for astma, allergi og overfølsomhet (RAAO) ved spørsmål. Vi minner om at ved anafylaksi bør man i serum måle tryptase og om mulig $\mathrm{sC}_{5} \mathrm{~b}-9$ 1-4 timer etter reaksjonen. $\mathrm{SC}_{5} \mathrm{~b}-9$ er en test for komplementforbruk og analyseres ved Oslo universitetssykehus og Nordlandssykehuset i Bodø. Det er spesielle krav til prøvetakningsprosedyre og forsendelse av denne prøven, noe som gjør at ikke alle har anledning til å gjennomføre dette.

\section{«Pasienter med allergiske reaksjoner på covid-19-vaksinen må henvises til utredning, både for pasientens del og for samfunnet»}

Legemiddelutløst anafylaksi er meldepliktig til det regionale legemiddelinformasjonssenteret (RELIS) og bør også meldes til Anafylaksiregisteret (7.).

Vi ønsker at flest mulig utredes for allergiske reaksjoner på covid-19-vaksinene. Utredning av allergiske reaksjoner på medikamenter som inneholder fyllstoffer (som polyetylenglykol og polysorbater), er etablert ved Seksjon for klinisk spesialallergologi, Regionalt senter for astma, allergi og anna overfølsemd i Helse Vest under Yrkesmedisinsk avdeling, Haukeland universitetssjukehus. Det etableres nå det samme tilbudet ved de regionale sentrene for astma, allergi og overfølsomhet i Tromsø, Trondheim og Oslo, slik at alle helseregioner vil ha mulighet til rask avklaring av pasientene. Pasienter med allergiske reaksjoner på covid-19-vaksinen må henvises til utredning, både for pasientens del og for samfunnet. 
1. Allergic reactions including anaphylaxis after receipt of the first dose of Pfizer-BioNTech COVID-19 vaccine - USA, December 14-23, 2020. MMWR Morb Mortal Wkly Rep 2021; 70: 46-51. [PubMed] [CrossRef]

2. Allergic reactions including anaphylaxis after receipt of the first dose of Moderna COVID-19 vaccine - United States, December 21, 2020-January 10, 2021. MMWR Morb Mortal Wkly Rep 2021; 70 : 125-9. [PubMed][CrossRef]

3. Garvey LH, Nasser S. Anaphylaxis to the first COVID-19 vaccine: is polyethylene glycol (PEG) the culprit? Br J Anaesth 2020; 125: Sooo7-0912(20)31009-6. [PubMed][CrossRef]

4. Banerji A, Wickner PG, Saff R et al. mRNA vaccines to prevent COVID-19 disease and reported allergic reactions: Current evidence and suggested approach. J Allergy Clin Immunol Pract 2020; 8: S2213-2198(20)31411-2. [PubMed][CrossRef]

5. Wenande E, Garvey LH. Immediate-type hypersensitivity to polyethylene glycols: a review. Clin Exp Allergy 2016; 46: 907-22. [PubMed][CrossRef]

6. Klimek L, Jutel M, Akdis CA et al. ARIA-EAACI statement on severe allergic reactions to COVID-19 vaccines - an EAACI-ARIA position paper. Allergy 2020; 75: all.14726. [PubMed][CrossRef]

7. Anafylaksiregisteret. https://www.anafylaksiregisteret.no Lest 12.2.2021.

Publisert: 16. februar 2021. Tidsskr Nor Legeforen. DOI: 10.4045/tidsskr.21.0109

Mottatt 10.2.2021, godkjent 12.2.2021.

(C) Tidsskrift for Den norske legeforening 2023. Lastet ned fra tidsskriftet.no 26. april 2023. 